\title{
Protective Effect of Sclerin on a Lead-acetate Injury Affecting the Growth and Porphyrin Metabolism in Rat
}

\author{
Makoto Taniguchi, Takashi Nishio and Yukio Satomura \\ Faculty of Science, Osaka City University, Osaka \\ Received September 25, 1975
}

\begin{abstract}
While a continuous ingestion of lead acetate added in drinking water suppressed the rat growth, depressing in some degree the level of hepatic $\delta$-aminolevulinate (ALA) dehydratase, a very small amount of sclerin (SCL) added simultaneously in the water restored the growth and dehydratase level. Moreover, subcutaneous injection of SCL to the rat not only maintained the ALA dehydratase level, but prevented a marked depression of the level of mitochondrial ALA synthetase in liver caused by intraperitoneal injection of lead acetate. Injection of SCL alone increased tolerably (about 1.8 times) the mitochondrial ALA synthetase, but little the extramitochondrial synthetase. The treatment by SCL was attended by a initial decrease, then a gradual increase in the activity of microsomal drug metabolizing enzyme.
\end{abstract}

Sclerin (SCL), a physiologically active substance produced by a strain of Sclerotinia libertiana, influences widely the growth and enzyme formation in various kinds of organisms including plants, microorganisms and animals. ${ }^{1 \sim 5}$ SCL has previously been reported to stimulate the formation and activity of peroxidase in the Sclerotinia fungus itself. ${ }^{5)} \mathrm{SCL}$ also stimulates the chlorophyll formation in plants and chlorella cells, reducing the phytotoxicity of agricultural chemicals such as 2, 4dichlorophenoxyacetate and phenylmercuric acetate. ${ }^{4,6)}$ Peroxidase is a heme enzyme and since heme and chlorophyll are both metal complexes of porphyrin, the above effects of SCL suggest a common regulatory function for synthesis of porphyrins.

The porphyrin synthesis in liver has a profound relation with the activity of microsomal mixed-function oxidase system, ${ }^{7 \sim 12)}$ which involves cytochrome $\mathrm{P}-450$, a heme protein, metabolizing steroids, drugs and 'foreign compounds.' Lately, we have found that SCL exhibits an activating effect in vitro on the microsomal aniline hydroxylase in rat liver tissues. ${ }^{4}$ ?

On the other hand, lead is known to inhibit in vitro the key enzymes in heme biosynthesis, ${ }^{13}$ and air-borne lead, an urban environmental poison, has been found to cause some abnor- malities in porphyrin metabolism. ${ }^{14}$ Also, lead acetate is a powerful inhibitor of protein synthesis in vitro. ${ }^{15)}$ In the present paper, effect of SCL on a lead-acetate injury in the rats was investigated in reference to the growth and porphyrin metabolism.

\section{MATERIALS AND METHODS}

Animals. Male Wistar rats were fed on a diet of Nippon Clea Co. CE-2 and water ad libitum.

Treatment of animals. For injection tests, rats $(100 \sim 130 \mathrm{~g})$ were fasted for $24 \mathrm{hr}$. Stock solution containing $0.1 \% \mathrm{SCL}$ was prepared by dissolving $\mathrm{SCL}$ in $0.1 \mathrm{~N} \mathrm{NaOH}$ and neutralizing with a diluted $\mathrm{HCl}$ solution to $\mathrm{pH} 6.6 \sim 6.8$ and was stored in a refrigerator. When SCL was employed, this stock solution was diluted by $0.9 \% \mathrm{NaCl}$ and given subcutaneously as indicated in respective tables. Lead acetate was dissolved in distilled water and administered by intraperitoneal injection. Control rat was treated by $0.9 \%$ $\mathrm{NaCl}$ unless otherwise stated. Rats were maintained fasting throughout the injection experiments.

\section{Assay of enzyme activity}

$\delta$-Aminolevulinate $(A L A)$ dehydratase. Rats were killed by decapitation and livers were removed in a chilled dish. The liver was homogenized with 20 vol. of $0.25 \mathrm{M}$ sucrose in Potter-Elvehjem homogenizer with a Teflon pestle, and the homogenate was centrifuged at $10,000 \times g$ for $15 \mathrm{~min}$. The supernatant was used as enzyme solution. Enzyme activity was estimated as described by Wilson et al., using the Thunberg tubes. ${ }^{16)}$ 
The tube contained $0.5 \mathrm{ml}$ of enzyme solution in $1.5 \mathrm{ml}$ of a reaction mixture of the following final composition: $0.02 \mathrm{M}$ reduced glutathione, $0.1 \mathrm{~m}$ sodium phosphate buffer (pH 6.8) and 0.01 M ALA. After evacuation and preincubation for $1 \mathrm{hr}$ at $37^{\circ} \mathrm{C}$, substrate was added from the cap of the tube. Incubation was then continued for additional $30 \mathrm{~min}$ and reaction was terminated by the addition of $1.5 \mathrm{ml}$ of $10 \%$ trichloroacetic acid (TCA) containing $0.1 \mathrm{M} \mathrm{HgCl}_{2}$. Porphobilinogen (PBG) formed was measured by the modified Ehrlich's method of Mauzerall and Granick. ${ }^{17}$ The enzyme activity was expressed as $\mu$ moles of $\mathrm{PBG}$ formed $/ \mathrm{hr} / \mathrm{g}$ liver.

ALA synthetase. The rat liver removed as described above was homogenized with $6 \mathrm{vol}$. of $0.25 \mathrm{M}$ sucrose containing $0.05 \mathrm{M}$ Tris- $\mathrm{HCl}$ buffer ( $\mathrm{pH} 7.5$ ), $0.025 \mathrm{M} \mathrm{KCl}, 0.025 \mathrm{M} \mathrm{MgCl}_{2}$ and $0.1 \mathrm{~mm}$ pyridoxal phosphate in Potter-Elvehjem homogenizer, and the homogenate was centrifuged at $800 \times g$ for $10 \mathrm{~min}$. Mitochondria were sedimented from the resulting supernatant solution by centrifugation at $10,000 \times g$ for $15 \mathrm{~min}$, and were washed and resuspended in the same medium. Enzyme activity was determined by the method of Hayashi et al ${ }^{18)}$ Reaction mixture contained $150 \mu$ moles Tris- $\mathrm{HCl}$ buffer (pH 7.5), $200 \mu$ moles glycine, $20 \mu$ moles succinate, $20 \mu$ moles ATP, $0.3 \mu$ moles pyridoxal phosphate, $0.3 \mu$ moles CoA, $10 \mu$ moles $\mathrm{MgCl}_{2}, 8 \mu$ moles EDTA, succinyl-CoA synthetase, catalysing the formation of $16.2 \mu$ moles of succinyl$\mathrm{CoA} / \mathrm{hr}$ and $1 \mathrm{ml}$ of mitochondrial suspension, in the final volume of $2 \mathrm{ml}$. The reaction was carried out in a test tube at $37^{\circ} \mathrm{C}$ for $60 \mathrm{~min}$ with shaking, and stopped by the addition of $0.5 \mathrm{ml}$ of $12.5 \%$ TCA. ALA formed was estimated as described by Narisawa and Kikuchi. ${ }^{18}$ ) The enzyme activity was expressed as nmoles of ALA formed $/ \mathrm{hr} / \mathrm{g}$ liver. The activity in cytosol was assayed by employing the $10,000 \times g$ supernatant fraction.

Aniline hydroxylase. Enzyme activity was measured by the method of Imai et al. ${ }^{20)}$ The liver perfused in situ with $0.9 \% \mathrm{NaCl}$ was homogenized with 4 vol. of $1.15 \% \mathrm{KCl}$ in Potter-Elvehjem homogenizer. The homogenate was centrifuged at $10,000 \times g$ for $15 \mathrm{~min}$. Microsomes were sedimented from the resulting supernatant solution by centrifugation at $105,000 \times g$ for $60 \mathrm{~min}$. The sediments of microsomes were washed once with $1.15 \% \mathrm{KCl}$ and resuspended in the same $\mathrm{KCl}$ solution. Reaction mixture contained $5 \mathrm{~mm}$ aniline, $0.5 \mathrm{~mm}$ NADP, $5 \mathrm{~mm}$ glucose-6-phosphate, $2.5 \mathrm{~mm}$ $\mathrm{MgCl}_{2}, 1$ unit of glucose-6-phosphate dehydrogenase, $8 \mathrm{~mm}$ nicotinamide, $100 \mathrm{~mm}$ Tris-acetate buffer ( $\mathrm{pH} 8.0)$ and $1 \mathrm{ml}$ of microsomal suspension, in the final volume of $2 \mathrm{ml}$. The reaction was carried out for $20 \mathrm{~min}$ at $37^{\circ} \mathrm{C}$ with shaking and stopped by the addition of $1 \mathrm{ml}$ of $20 \%$ TCA. After centrifugation $p$-aminophenol formed was assayed in $1 \mathrm{ml}$ of the supernatant after adding $0.5 \mathrm{ml}$ of $10 \% \mathrm{Na}_{2} \mathrm{CO}_{3}$ and $1 \mathrm{ml}$ of $2 \%$ phenol in $0.2 \mathrm{~N} \mathrm{NaOH}$ by measuring the $E_{630}$ after $30 \mathrm{~min}$. The enzyme activity was expressed as $\mu$ moles of $p$ aminophenol formed $/ \mathrm{min} / \mathrm{g}$ liver.

Chemicals. SCL was prepared from the extract of a bran culture of Sclerotinia libertiana.,21) Other chemicals used were obtained from the following sources: glucose-6-phosphate dehydrogenase (EC 1.1.1. 49), from Boehringer Mannheim Biochemical Co.; succinyl-CoA synthetase (EC 6.2.1.4), ALA and PBG, from Sigma Chemical Co.; pyridoxal phosphate and reduced glutathione, from Fluka Co.; CoA, ATP, NADP and glucose-6-phosphate, from Kyowa Hakko Kogyo Co., Ltd.

\section{RESULTS}

Effect of SCL and lead acetate on the rat growth As shown in Tables I and II, when lead acetate was administered in drinking water

TAble I. Effect of SCL and Lead Acetate on the Rat Growth

\begin{tabular}{lcccc}
\hline \multirow{2}{*}{ Administration } & \multicolumn{3}{c}{ Body weight $(\mathrm{g})^{c)}$} & Significance $_{(\boldsymbol{P})}$ \\
& Initial & Final & Gain & \\
\hline Control & $75.0 \pm 4.7$ & $281.0 \pm 16.6$ & $206.0 \pm 16.9$ & \\
SCL $^{a)}$ & $75.0 \pm 2.6$ & $288.5 \pm 13.4$ & $213.5 \pm 9.8$ & N.S. \\
Lead acetate $^{b)}$ & $72.8 \pm 4.4$ & $259.4 \pm 28.7$ & $186.6 \pm 30.5$ & $<0.2$ \\
SCL +lead acetate & $79.2 \pm 5.1$ & $291.0 \pm 16.4$ & $211.8 \pm 13.3$ & N.S. \\
\hline
\end{tabular}

a) $\mathrm{SCL}$ was continuously administered in drinking water at $0.1 \mu \mathrm{g} / \mathrm{ml}$.

b) Lead acetate was continuously administered in drinking water at $0.1 \%$ for the first 18 days, $0.2 \%$ for 4 days, $0.3 \%$ for 8 days, $0.4 \%$ for 4 days and then $0.5 \%$ for the last 2 days.

c) Rats were fed on a diet of Nippon Clea Co. CE-2 (crude protein $24 \%$ ) and drinking water ad libitum for 36 days. The values are means \pm S.D. of 5 animals.

d) Significance was statistically calculated refferring to control. For $P$ values greater than 0.2 , the term N.S. (not significant) was employed. 
Table II. Effect of SCl and Lead Acetate on the Rat Growth

\begin{tabular}{|c|c|c|c|c|}
\hline \multirow{2}{*}{ Administration } & \multicolumn{3}{|c|}{ Body weight $(\mathrm{g})^{\mathrm{c})}$} & \multirow{2}{*}{$\begin{array}{c}\text { Significance } \\
(P)\end{array}$} \\
\hline & Initial & Final & Gain & \\
\hline Lead acetate ${ }^{\alpha)}$ & $73.2 \pm 4.5$ & $247.4 \pm 24.1$ & $174.2 \pm 23.9$ & \\
\hline Lead acetate $+\mathrm{SCL}^{b)}$ & $73.6 \pm 4.7$ & $266.0 \pm 14.0$ & $192.4 \pm 13.9$ & $<0.02$ \\
\hline
\end{tabular}

a) Lead acetate was intermittently ( 2 days within 1 week) administered in drinking water, with the gradual increase in concentration $(0.2 \%$ for the first 1 week, $0.3 \%$ for the second 1 week, $0.4 \%$ for the third 1 week and $0.5 \%$ for the last 3 weeks).

b) SCL was also intermittently (1 day within 5 days) administered in drinking water at $0.5 \mu \mathrm{g} / \mathrm{ml}$.

c) Rats were kept for 37 days as in Table 1 . The values are means $\pm S . D$. of 10 animals.

d) Significance was statistically calculated refferring to lead acetate alone.

daily or intermittently at an interval of days for $36 \sim 37$ days, the young rats suffered an injurious effect on growth, reducing the gain of body weight. In contrast, a very small amount of SCL administered simultaneously in the drinking water protected somatic development of the rats and restored the body weight gain. SCL alone had little effect on the rat growth under such conditions. SCL was supposed to give a biochemical effect on the rats. As shown in Table III, though the ingestion of lead acetate

Table III. Effect of SCL and Lead Acetate on the Level of Hepatic ALA Dehydratase

\begin{tabular}{lc} 
Administration $^{a)}$ & $\begin{array}{c}\text { ALA dehydratase activity } \\
\mu \text { moles of PBG } \\
\text { formed } / \mathrm{hr} / \mathrm{g} \text { liter }\end{array}$ \\
\hline Control & $1.41 \pm 0.08$ \\
SCL & $1.53 \pm 0.13$ \\
Lead acetate & $1.14 \pm 0.10$ \\
SCL + lead acetate & $1.30 \pm 0.04$ \\
\hline
\end{tabular}

a) The same as in Table I.

b) The activity was assayed at the 36 th day. The values are means \pm S.D. of 5 animals.

for 36 days depressed to some extent the level of hepatic ALA dehydratase in the rats, combination of SCL and lead acetate just maintained the level. Ingestion of SCL alone had little effect on the level. It was indicated that some interactions between SCL and lead acetate occurred on the porphyrin metabolism in the rats during the growth.

Effect of SCL and lead acetate on level of the $A L A$ dehydratase and synthetase in liver

As shown in Table IV, while intraperitoneal
Table IV. Restoring EfFect of SCL on the Level of Hepatic Ala Dehydratase Depressed BY LEAD ACETATE

\begin{tabular}{lc}
\hline Administration & \\
\hline Control & $\begin{array}{c}\text { ALA dehydratase activity } \\
\mu \text { moles of PBG } \\
\text { formed } / \mathrm{hr} / \mathrm{g} \text { liver }\end{array}$ \\
\hline SCL & $1.57 \pm 0.09(100.0 \%)^{c)}$ \\
Lead acetate & $1.62 \pm 0.06(103.2)$ \\
SCL + lead acetate & $0.63 \pm 0.17(40.1)$ \\
\hline
\end{tabular}

a) SCL $(10 \mu \mathrm{g} / 100 \mathrm{~g}$ body weight) was subcutaneously, and lead acetate $(30 \mathrm{mg} / 100 \mathrm{~g}$ body weight) was intraperitoneally injected.

b) The activity was assayed $24 \mathrm{hr}$ after injection. The values are means $\pm S$.D. of 3 animals.

c) Parenthesis shows relative activity.

injection of lead acetate $(30 \mathrm{mg} / 100 \mathrm{~g}$ body weight) depressed the level of ALA dehydratase approximately to $40 \%$ of control after $24 \mathrm{hr}$, subcutaneous injection of SCL $(10 \mu \mathrm{g} / 100 \mathrm{~g})$ performed simultaneously prevented the depression, maintaining more than $80 \%$ of the control level of the dehydratase. SCL alone hardly affected the level. This may indicate that the interaction between SCL and lead acetate did not occur only on the level of ALA dehydratase.

As shown in Table $\mathrm{V}$, the injection of SCL had an inducing effect on the ALA synthetase in the liver, and increased specially the enzyme activity in mitochondria at a small dosage, $1 \mu \mathrm{g}$ per $100 \mathrm{~g}$ body weight. The effect of SCL attained to a peak at $10 \mu \mathrm{g}$ and increased the activity in mitochondria about 1.8 times, but only slightly in the soluble part. The mitochondrial ALA synthetase is known to differ 
from the soluble enzyme in molecular size, the former being smaller than the latter. ${ }^{22)}$ Contrary to this, as shown in Table VI, the injection

TABLE V. EFFECT OF SCL ON THE LEVEL OF Hepatic Mitochondrial ala Synthetase

\begin{tabular}{|c|c|c|c|}
\hline \multirow{2}{*}{$\begin{array}{c}\left.\mathrm{SCL}{ }^{a}\right) \\
\mu \mathrm{g} / 100 \mathrm{~g} \\
\text { body weigh }\end{array}$} & \multicolumn{3}{|c|}{$\begin{array}{l}\text { ALA synthetase activity } \\
\text { nmoles of ALA formed/hr/g liver }\end{array}$} \\
\hline & Mitochondria & Cytosol & Total \\
\hline 0 & $\begin{array}{c}52.7 \pm 4.8 \\
(100.0 \%)^{\circ}\end{array}$ & $12.1 \pm 2.1$ & $64.8 \pm 5.9$ \\
\hline 1 & $\begin{array}{l}91.7 \pm 7.2 \\
(174.0)\end{array}$ & $14.6 \pm 3.0$ & $106.3 \pm 8.0$ \\
\hline 10 & $\begin{array}{l}98.0 \pm 12.7 \\
(186.0)\end{array}$ & $15.6 \pm 1.9$ & $113.6 \pm 13.1$ \\
\hline 50 & $\begin{array}{l}81.2 \pm 11.3 \\
(154.1)\end{array}$ & $13.3 \pm 3.4$ & $94.5 \pm 11.9$ \\
\hline
\end{tabular}

a) SCL was administered by subcutaneous injection.

b) The activity was assayed $24 \mathrm{hr}$ after injection. The values are means $\pm S$.D. of 3 animals.

c) Parenthesis shows relative activity.

Table VI. Restoring Effect of SCL on the Level of Hepatic Mitochondrial ALA Synthetase Depressed by Lead Acetate

\begin{tabular}{|c|c|c|c|}
\hline \multirow{2}{*}{$\begin{array}{l}\text { Admini- } \\
\text { stration }^{a} \text { ) }\end{array}$} & \multicolumn{3}{|c|}{$\begin{array}{l}\text { ALA synthetase activity } \\
\text { nmoles of ALA formed } / \mathrm{hr} / \mathrm{g} \text { liver }\end{array}$} \\
\hline & Mitochondria & Cytosol & Total \\
\hline Control & $\begin{array}{l}53.8 \pm 6.0 \\
(100.0 \%)\end{array}$ & $13.3 \pm 2.4$ & $67.1 \pm 6.2$ \\
\hline SCL & $\begin{array}{l}96.1 \pm 15.2 \\
(178.6)\end{array}$ & $16.0 \pm 1.8$ & $112.1 \pm 14.7$ \\
\hline Lead acetate & $\begin{array}{l}15.7 \pm 3.9 \\
(29.2)\end{array}$ & $82.9 \pm 17.3$ & $98.6 \pm 18.1$ \\
\hline $\begin{array}{l}\mathrm{SCL}+ \\
\text { lead acetate }\end{array}$ & $\begin{array}{l}48.6 \pm 8.1 \\
(90.3)\end{array}$ & $78.6 \pm 19.5$ & $127.2 \pm 20.2$ \\
\hline
\end{tabular}

a) $\mathrm{SCL}(10 \mu \mathrm{g} / 100 \mathrm{~g}$ body weight) was subcutaneously, and lead acetate ( $30 \mathrm{mg} / 100 \mathrm{~g}$ body weight) was intraperitoneally injected.

b) The activity was assayed $24 \mathrm{hr}$ after injection. The values are means \pm S.D. of 3 animals.

c) Parenthesis shows relative activity.

of lead acetate $(30 \mathrm{mg} / 100 \mathrm{~g})$ markedly decreased the mitochondrial ALA synthetase with rather increasing the 'soluble form.' When SCL and lead acetate were simultaneously administered, the level of mitochondrial synthetase was maintained approximately normal, but that of the 'soluble form' con- siderably increased. Accordingly, it was proved that the level of ALA dehydratase in liver had a close relation with the mitochondrial synthetase, but no relation with the soluble enzyme.

\section{Effect of SCL on level of the microsomal aniline hydroxylase in liver}

As presented in Fig. 1, the injection of SCL at $10 \mu \mathrm{g}$ per $100 \mathrm{~g}$ body weight, at first, rapidly

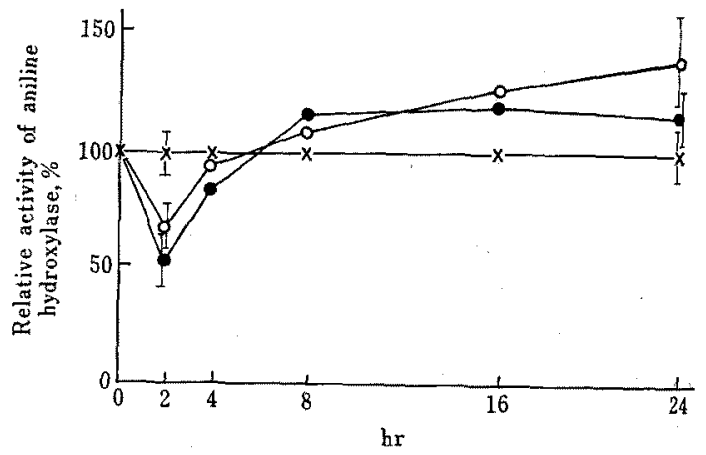

FIG. 1. Time Course of Change in the Level of Microsomal Aniline Hydroxylase after SCL Injection.

The activity was assayed $2,4,8,16$ and $24 \mathrm{hr}$ after subcutaneous injection, respectively, as described in MATERIALS AND METHODS and the relative activity was represented as \% of control. Each point is mean with S.D. (bar) of 3 animals.

$x-x$, control; $\bigcirc-0,10 \mu \mathrm{g}$ SCL/100 g body weight;

-, $50 \mu \mathrm{g} \mathrm{SCL} / 100 \mathrm{~g}$ body weight.

lowered the level of microsomal aniline hydroxylase in the liver, but soon restored raising the level gradually within $24 \mathrm{hr}$. The effect of SCL resembled a pattern of the enzyme regulation by certain porphyrinogenic drug such as allylisopropylacetamide. ${ }^{10,23)}$ Though the injection of SCL at $50 \mu \mathrm{g}$ also exhibited a similar effect initially, the rise in the level of aniline hydroxylase did not continue from $8 \mathrm{hr}$ forth and equilibrated with control. Administration of an excessive amount of SCL may produce some harmful effect on the enzyme induction.

\section{DISCUSSION}

As shown in the above experiments, though the intraperitoneal injection of lead acetate 
increases the 'soluble form' of ALA synthetase in liver, it markedly decreases the mitochondrial synthetase. ALA synthetase is believed to be synthesized originally in the microsomal system and subsequently transferred into mitochondria where it settles, accompanying the modification of the enzyme protein. ${ }^{22,24)}$ The soluble ALA synthetase may be a precursor of the mitochondrial ALA synthetase. Lead acetate appears to inhibit the transfer of soluble ALA synthetase into mitochondria, because mitochondria of liver Kupffer and parenchymal cells are known to be structurally altered by non-toxic doses of lead. ${ }^{14,25}$ ) On the other hand, administration of SCL to the rat increases the mitochondrial ALA synthetase and prevents the depression by lead acetate of the level of the mitochondrial synthetase. This may be due to a protective effect of SCL on the structure and function of mitochondrial membrane. ${ }^{26)}$ It has previously been shown that SCL stimulates the transfer of proteins synthesized in extramitochondrial system into mitochondria. ${ }^{27}$

The ALA synthesized in mitochondria is then transferred into cytosol and may induce the ALA dehydratase, an extramitochondrial enzyme. Administration of porphyrinogenic drugs or ALA to animals is known to increase the dehydratase. ${ }^{28,291}$ The exit of ALA from the mitochondria is a possible site of metabolic regulation. ${ }^{13}$ It seems reasonable that $\mathrm{SCL}$ restores the level of ALA dehydratase depressed by lead acetate through the induction of mitochondrial ALA synthetase. It was found that SCL hardly affects the level of ALA dehydratase maintained in normal, regardless of the elevation of mitochondrial synthetase. This may imply the regulation of porphyrin metabolism by the so-called 'succinate-glycine cycle' in mitochondria, regenerating succinate or succinyl-CoA from ALA.

Regarding the effect of SCL on microsomal aniline hydroxylase, initial decrease in the enzyme activity was noticed, which suggests the involvement of the degradation of cytochrome P-450 in the induction of ALA synthetase by SCL, as in the case with allylisopropyla- cetamide, a potent porphyrinogenic drug. ${ }^{7 \sim 12}$, On the other hand, potency of SCL on the ALA synthetase induction is not so high but rather resembles with phenobarbital, a weaker porphyrinogenic drug, which markedly increases cytochrome P -450 content. ${ }^{12}$ ) These drugs are known to elicit an increase in liver weight, microsomal protein, RNA and phospholipid contents as well as the rate of protein synthesis, in vivo and in vitro. ${ }^{12,30 \sim 32)} \mathrm{SCL}$ also has a stimulatory effect on protein synthesis in vitro in extramitochondrial system, as reported previously. ${ }^{2,4,27)}$ There may be a common basis involving the anabolic effects in the regulation of microsomal mixed-function oxidase system coupled with the ALA synthetase induction. Also, for further elucidating the induction mechanism of ALA synthetase by SCL, detailed studies are necessary on interaction of SCL with some steroid metabolite or heme, acting as a derepressor or corepressor respectively in the heme biosynthesis. ${ }^{33 \sim 36)}$

\section{REFERENCES}

1) Y. Satomura and A. Sato, Agr. Biol. Chem., 29 , 337 (1965).

2) S. Oi, T. Kusumi, I. Matsui and Y. Satomura, ibid., 36, 604 (1972).

3) M. Yamaguchi, M. Kato, S. Oi and Y. Satomura, ibid., 37, 599 (1973).

4) Y. Satomura, Proceedings 8 th International Conference on Plant Growth Substances, Tokyo, 1973, p. 1197.

5) S. Marukawa, S. Funakawa and Y. Satomura, Agr. Biol. Chem., 39, 645 (1975).

6) Y. Satomura, Chen. Regul. Plants, 3, 127 (1968).

7) F. De Matteis, FEBS Lett., 6, 343 (1970).

8) S. A. Landaw, C. W. Callahan and R. Schmid, J. Clin. Invest., 49, 914 (1970).

9) U. S. Meyer and H. S. Marver, Science, 171, 64 (1971).

10) M. R. Satyanarayana Rao, K. Malathi and G. Padmanaban, Biochem. J., 127, 553 (1972).

11) G. Padmanaban, M. R. Satyanarayana Rao and K. Malathi, ibid., 134, 847 (1973).

12) M. R. Satyanarayana Rao and G. Padmanaban, ibid., 134, 859 (1973).

13) A. Cantarow and B. Schepartz, "Biochemistry," W. B. Saunders Co., Philadelphia and London, 1967, p. 611 .

14) R. M. Hicks, Chem.-Biol. Interact., 5, 361 (1972). 
15) H. Borsook, E. R. Fischer and G. Keighley, $J$. Biol. Chem., 229, 1059 (1957).

16) E. L. Wilson, P. E. Burger and E. B. Dowdle, Eur. J. Biochem., 29, 563 (1972).

17) D. Mauzerall and S. Granick, J. Biol. Chem., 219, 435 (1956).

18) N. Hayashi, B. Yoda and G. Kikuchi, Arch. Biochem. Biophys., 131, 83 (1969).

19) K. Narisawa and G. Kikuchi, Biochim. Biophys. Acta, 123, 596 (1966).

20) Y. Imai, A. Ito and R. Sato, J. Biochem. (Tokyo), 60, 417 (1966).

21) T. Kubota, T. Tokoroyama, T. Kamikawa and Y. Satomura, Tetrahedron Lett., 42, 5205 (1966).

22) N. Hayashi, B. Yoda and G. Kikuchi, J. Biochem. (Tokyo), 67, 859 (1970).

23) F. De Matteis, Biochem. J., 124, 767 (1971).

24) N. Hayashi, Y. Kurashima and G. Kikuchi, Arch. Biochem. Biophys., 148, 10 (1972).

25) N. R. Diluzio, R. A. Trejo and E. Hoffimann, Abstracts of Papers, 5th Meeting of the International Association for the Study of the Liver,
Versailles, 1972.

26) M. Yamaguchi and Y.Satomura, Agr. Biol. Chem., 38, 1289 (1974).

27) M. Yamaguchi and Y. Satomura, ibid., 39, 1559. (1975).

28) J. Onisawa and R. F. Labbe, Biochim. Biophys. Acta, 56, 618 (1962).

29) D. P. Tschudy, M. G. Perlroth, H. S. Marver, A. Collins, G. Hunter, Jr. and M. Rechcigl, Jr., Proc. Natl. Acad. Sci. U.S., 53, 841 (1965).

30) R. Kato, L. Loeb and H. V. Gelboin, Biochem. Pharmacol., 14, 1164 (1965).

31) M. R. Jachau and J. R. Fouts, ibid., 15, 1453 (1966).

32) H. S. Marver, A. Collins, D. P. Tschudy and M. Rechcigl, Jr., J. Biol. Chem., 241, 4323 (1966).

33) S. Granick, ibid., 241, 1359 (1966).

34) S. Granick and A. Kappas, Proc. Natl. Acad. Sci. U.S., 57, 1463 (1967).

35) A. Kappas and S. Granick, J. Biol. Chem., 243, 346 (1968).

36) B. F. Burnham, Metab. Pathways, 3, 403 (1969). 